Canadian University Music Review

Revue de musique des universités canadiennes

\title{
Royal S. Brown. Overtones and Undertones: Reading Film Music. Berkeley: University of California Press, 1994. x, 396 pp. ISBN 0-520-08320-2 (paperback)
}

\section{Philippe Mather}

Volume 19, numéro 1, 1998

URI : https://id.erudit.org/iderudit/1014619ar

DOI : https://doi.org/10.7202/1014619ar

Aller au sommaire du numéro

Éditeur(s)

Canadian University Music Society / Société de musique des universités canadiennes

ISSN

0710-0353 (imprimé)

2291-2436 (numérique)

Découvrir la revue

Citer ce compte rendu

Mather, P. (1998). Compte rendu de [Royal S. Brown. Overtones and Undertones: Reading Film Music. Berkeley: University of California Press, 1994. x, 396 pp. ISBN 0-520-08320-2 (paperback)]. Canadian University Music Review / Revue de musique des universités canadiennes, 19(1), 120-121.

https://doi.org/10.7202/1014619ar

All Rights Reserved @ Canadian University Music Society / Société de musique des universités canadiennes, 1998
Ce document est protégé par la loi sur le droit d'auteur. L'utilisation des services d'Érudit (y compris la reproduction) est assujettie à sa politique d'utilisation que vous pouvez consulter en ligne.

https://apropos.erudit.org/fr/usagers/politique-dutilisation/ 
sémantiques, la fonction des syllabes sans signification, la métrique et la musique des jeux chantés.

À notre avis, la qualité de cet ouvrage tient à la clarté de son architecture et à la minutie de l'analyse des contenus linguistiques et musicaux des divers corpus retenus. Les nombreux tableaux et extraits musicaux, les index et les documents photographiques illustrent les propos avec pertinence. Cette étude apporte un éclairage documenté et nouveau sur diverses facettes du répertoire enfantin et particulièrement sur les rapports entre la poésie, la musique et les gestes des jeux chantés. En raison de la terminologie et des codes graphiques propres aux sujets étudiés, ce livre s'adresse avant tout à un public de chercheurs intéressés aux domaines musilinguistiques de cet « art de l'enfance ».

Francis Corpataux

Royal S. Brown. Overtones and Undertones: Reading Film Music. Berkeley: University of California Press, 1994. x, 396 pp. ISBN 0-520-08320-2 (paperback).

In the world of academic book publishing, Royal S. Brown's Overtones and Undertones: Reading Film Music belongs not to the revised doctoral thesis genre, but rather the loose gathering of articles written on a general topic, in this case film music. This second genre will not always produce a theoretically coherent text, though the quantity or the quality of the information contained within need not be affected. Such is the case with Brown's study. There is no common theme which runs through the eight chapters of this text, beyond the topic of film music. The introduction spells out some basics in music theory for the non-musician (consonance, dissonance, major, minor, etc.); the third chapter provides an overview of the history of film music; the first and fourth chapters describe some narrative functions; and chapters 5, 6, and 7 contain for the most part analyses of specific films. Even the more theoretical chapters appear to be characterized by a methodological eclecticism: there are elements of semiology and feminist/psychoanalytic theory, along with a discussion of postmodernism. The references to semiology are not the most current, when one considers the presence on p. 31 of Danish linguist Louis Hjelmslev's schema for the structure of connotation, as used by Roland Barthes in his 1957 book, Mythologies (both the sign's denotative and connotative levels possess a signifier and a signified; together, the denotation's signifier and signified make up the connotation's signifier). Reading the passages where the notion of fetishism is discussed, one hears echoes of the writings of Kaja Silverman in The Acoustic Mirror (Bloomington: Indiana University Press, 1988) and Kathryn Kalinak in Settling the Score (Madison: University of Wisconsin Press, 1992). No new ground is broken by Brown's definition of postmodernism on p. 235, which is followed by a series of analyses that mostly do not appear to foreground anything specifically "postmodern." Brown deals with a number of issues, but once again, no theme appears to emerge: the eighth chapter is a series of comments on "postmodern" films. In a surprisingly brief conclusion, Brown suggests that new interactive media undermine "the mod- 
ernist construct of the bourgeois individual subject" (p. 267), when it could easily be argued that the spectator/listener, as a subject in these interactive media, is even more of an auteur than before. There are a number of observations in the first two chapters about the origins of film music (Greek theatre, melodrama, opera) and its various aesthetic and narrative functions which have been more than adequately discussed previously, in Claudia Gorbman's Unheard Melodies (London: BFI Publishers, 1987).

Nevertheless, Overtones and Undertones remains a very useful reference on a number of levels. The book concludes with interviews with eight film composers, including Miklós Rózsa, David Raksin, Bernard Herrmann, and Henry Mancini. This is followed by a pedagogically useful outline entitled "How to hear a movie," which is broken into different aspects of film music that students can focus on: styles, generic and narrative functions, extra-filmic or contextual considerations. The third chapter on the history of film music includes some original information, and the sixth chapter is an excellent analysis of Herrmann's musical style, even though Graham Bruce's booklength study of Herrmann's music covered the topic in a satisfactory fashion (Bernard Herrmann: Film Music and Narrative [Ann Arbor, Mich.: UMI Research Press, 1985]).

In some ways, Brown's study is a happy compromise between Gorbman's Unheard Melodies and Roy Prendergast's Film Music: A Neglected Art (New York: Norton, 1977). It is a more scholarly text than Prendergast's, but does not open new theoretical avenues that Gorbman did not deal with ten years previously. On the other hand, there is a wealth of historical and musical observations that demonstrate Brown's competence as a musician and his knowledge of film and film music in particular.

Philippe Mather

Jeremy Tambling. Opera and the Culture of Fascism. Oxford: Clarendon Press; New York: Oxford University Press, 1996. x, 274 pp. ISBN 0-19816566-8 (hardcover).

The aim of this book is to show how opera was part of the culture which led to the fascist regimes of the twentieth century. Its author, a professor of comparative literature, wishes to "take opera out of the hermetically sealed state in which it is normally discussed." He warns his reader that:

Opera is a weave of voices, a dialogue between text, music, and performance, and a mixed genre ... but it also has its political unconscious because of the dominant and the marginal discourses that emerge through each opera, which do not reduce to the pairing of music and libretto ... But in wishing to go beyond treating everything extraneous to the opera as mere "background," this book will tax the patience of those who "only" like opera. ... Musicians who prefer the formalist approach to opera analysis may reflect on the consequent marginalization of music and opera from the writing of cultural history (pp. 8-9). 